\title{
Protected Places
}

As a member of a former imperial dynasty, Anicia Juliana was well-to-do. When Justinian learned of Anicia Juliana's extensive wealth, he asked her to lend it to the public treasury to fund his military activities. But Anicia Juliana avoided obliging the emperor. She hastily commissioned craftsmen to use all her gold to adorn the ceiling of a church she had founded, Saint Polyeuktos at Constantinople. Then she took Justinian to the church and said, "Most glorious Augustus, I ask that you look at the ceiling of this church and realize that my poorness is kept there in this craftsmanship. But you now do what you wish. I will not oppose you." ${ }^{1}$ The emperor was embarrassed.

This is a story that Gregory of Tours relates in his Glory of the Martyrs. ${ }^{2}$ Whether fact or fiction, the punch line of the story assumes the legal principle that jurists and bishops applied to res sacrae: sacred things are divinely protected. Once a thing became sacred, it could be put to no other use. It could not be sold, exchanged, bequeathed, or made the object of any transaction. Once it became sacred, it remained sacred forever. In the story, Anicia Juliana kept her wealth from funding Justinian's military activities by making it all sacred. Though she invited Justinian to avail himself of the sacred assets, she knew that legal regulations to which he had lent his own weight would prevent him from doing so. Justinian was embarrassed because Anicia Juliana found a clever way to refuse his request.

According to Synesius of Cyrene, Paul, the bishop of Erythrum, had used the process of creating res sacrae to claim an area of another bishop's jurisdiction. In Gregory of Tours's story, Anicia Juliana also takes advantage of the legal category of sacred things. Her goal, however, is the opposite of Paul's: to keep her territory out of another's control (whereas Paul tried to bring another person's territory into his control). She donates her extensive golden assets to a church to prevent Justinian from staking a claim to it.

This chapter will begin with an analysis of jurists' pedagogy on the divinely protected status of res sacrae and then turn to laws and canons formulated from the 
fourth through sixth centuries. According to laws and canons, it was the bishop's duty to treat ecclesial properties as divinely protected things. A case study of the trials of Ibas of Edessa shows how he was charged with the crime of sacrilege for his failure to protect ecclesial property. A case study of Dioscorus of Alexandria's trial at the Council of Chalcedon in 451 shows how a council could ratify a bishop's protective measures even while deposing the bishop.

Canons of various synods highlight the period of transition between one bishop's death and his successor's accession as a particularly vulnerable time for res sacrae. To guarantee the security of ecclesial property during the vacancy of the see, bishops would use their last will and testament to continue administering the property until a successor would assume office. A case study on the contested episcopacy of Symmachus of Rome offers a concrete example of how ecclesial property could be administered through the use of a legal document, the will, and how relationships between church and state were negotiated in the process.

In general, civil laws did not attempt to regulate sacred things on behalf of ecclesiastical authorities but were probably only composed in response to ecclesiastical requests for civil enforcement of canons or to maintain the integrity of civil institutions. Bishops like Symmachus of Rome nevertheless asserted the primacy of their discretion over ecclesiastical matters.

\section{ROMAN JURISTIC PEDAGOGY ON THE PROTECTION OF RES SACRAE}

Gaius's textbook for students of law set up two different categories of things: human and divine. The primary distinguishing feature was that whereas human things are ownable, divine things are not. "What is under divine law," says Gaius, "belongs to no one" (quod autem divini iuris est, id nullius in bonis est). ${ }^{3}$ The principle that res sacrae belong to no one became a significant legacy of Gaius's thought. Sacred things were protected from ownership. Of course, this leaves unanswered the question of who may take responsibility for res sacrae when decisions must be made about them. By contrast, Ulpian's textbook categorized sacred things in a way that acknowledged what divine protection regularly meant: direct oversight on the part of the highest governmental officials. Ulpian grouped res sacrae with imperial offices, producing the shared characteristics of laws and churches as inviolable, and protected by God. ${ }^{4}$ Justinian's new and updated textbook repeated the principle noted in Gaius's Institutes (quod enim divini iuris est, id nullius in bonis est), while Justinian's laws show him regularly making decisions about them. ${ }^{5}$

Pedagogical contexts supply easily comprehensible analogies for the purpose of teaching the concept of inalienability. Jurists likened res sacrae to free persons. Just as a person's status as "free" protected him or her from becoming the object of a sale, usucaption (possession of a thing through long, uncontested use), or stipulation (making a thing the condition of an agreement), so also res sacrae enjoyed the 
same protections. Paul, a jurist of the early third century, uses the same analogy to describe the act of "consecration" as a loss of possession: "There is a variety of ways in which we lose possession; [ ... ] for we cannot possess a [ . . ] sacred place, even though we personally spurn religion and regard the land as private; the same is true of a free man (homo liber)."6 The status of consecrated land as "unowned" was no more contestable than a person's status as "free."

The analogy surfaces again in discussions of usucaption and stipulations. In Gaius's list of corporeal things that cannot be the object of usucaption, "sacred and dedicated things" stand alongside "freemen." Gaius invokes the analogy to explain that stipulations are automatically invalid if the stipulation cannot be fulfilled:

If the thing which we stipulated to be given is of such a nature that it cannot be given, it is plain that the stipulation is on natural reason invalid, for example, if a stipulation with respect to a freeman $[\ldots$. ] was made between persons who were unaware that the man was free [...]. The legal position is the same if someone has stipulated that a sacred or religious place be given. ${ }^{8}$

In other words, a stipulation that a free man be given is just as invalid as a stipulation that a res sacra be given. Free persons and sacred things were by nature inalienable. Paul makes the same point except in a different context, in a discussion about stipulations that depend on a future outcome. The stipulation "do you promise to deliver him when he becomes a slave" is no more valid than "[do you promise] to convey that plot of land when it ceases to be sacred or religious and becomes secular." Stipulations could not anticipate a future change in the nature of a person or thing. Paul sums up the matter as follows, "I will stipulate without effect for sacred or religious objects [ . . . ] or for a free person." ${ }^{10}$ Justinian's textbook also compares sacred things to free persons. According to Justinian's Institutes 2.6.1, res sacrae could not be the objects of usucaption, the subjects of stipulations, or the objects of sale. Their monetary assets too were inalienable. ${ }^{11}$ They could no more be objects of usucaption than a free man could be, even if they were possessed in the utmost good faith.

Justinian adds another analogy: res sacrae are like nonexistent things. A hippocentaur (a nonexistent thing) cannot be the subject of stipulations; the same is true of res sacrae. ${ }^{12}$ Like free persons, res sacrae were not things at all. They were nonexistent for the purposes of stipulation as well as usucaption or sale.

It was also outside the realm of legal possibility to bequeath res sacrae. Ulpian treats the notion as a matter of absurdity. Only a madman would try to bequeath inalienable things. ${ }^{13}$

Not even disasters affected the legal status of sacred things. According to Papinian (fl. 194-212), if an aedes sacra (a sacred building) is destroyed by an earthquake, the land nevertheless retains its legal status as sacred. It remains inalienable and cannot be sold despite the natural disaster. ${ }^{14}$ According to Pomponius, a second-century jurist, sacred land that was captured by an enemy would only 
cease to be sacred while it was in the enemy's hands. Once it was restored, the site would regain its legal status as sacred and would thereby be inalienable. ${ }^{15}$ Again, the person-thing analogy is invoked: Pomponius says the site is restored as a kind of postliminium. Just as a citizen loses his or her rights and property as a captive, but all is restored if he or she returns to the Roman patrimony, so too res sacrae lose their status under captivity, but regain it on release from enemy hands.

Though res sacrae were inalienable, the situation could arise in which an inalienable thing were sold as though it were alienable. There are two different opinions among the jurists about the validity of such a sale. Pomponius considered such a sale to be valid, drawing the frequently used analogy of free persons to sacred things: "The purchase of a freeman or of sacred or religious land who or which cannot be held as property is considered valid, so long as the purchaser does not know." ${ }^{16}$ The transaction was valid so long as it was made in good faith on the part of the purchaser. Modestinus (fl. 223-39), on the other hand, maintained that the transaction is invalid no matter what. Whether the purchaser could sue the vendor depended on circumstances related to the vendor. If the vendor sold the item in good faith, no action was possible, but if he did so in bad faith, then the purchaser could collect damages because of the deception. ${ }^{17}$ Modestinus regarded the sale of sacred land as automatically invalid; Pomponius regarded such a sale as invalid only if the purchaser obtained it in bad faith.

By way of preventing such a situation in the first place, a particular clause could be included in the sale contract: "If any of the land be sacred or religious, it is not included in the sale." 18 According to Paul, if the entirety of the purchased land was sacred or religious and the contract included such a clause, the purchaser could recover what he paid by legal action. ${ }^{19}$ According to Ulpian, such a clause allowed one to exclude particular tracts from the contract, even though they lay within the boundaries specified in the contract. ${ }^{20}$

Because res sacrae were not subject to alienation, their potential market value could not be determined. As Ulpian wrote, "A sacred thing does not receive appraisal." 21

The Praetor's Edict prohibited damage to res sacrae. There were at least three interdicts in the Praetor's Edict pertaining to res sacrae, all intended to prevent unauthorized change in the property's condition. Ulpian cites a prohibitive interdict, "The praetor says: 'I forbid doing anything in a sacred place, or introducing anything into it," and comments that the prohibition does not apply to acts of embellishment, but to acts of "defacement" (deformitatis) and "nuisance" (incommodi). ${ }^{22}$ Ulpian cites two more interdicts; these enjoin restitution. One pertains to illegal construction on sacred property: "if work has been carried out which ought not to have been, [ . . . ] recourse must be had [ . . ] to the interdict [ . . ] 'for restoration of something done in a consecrated [ . . . ] place."'23 This interdict on restoration of any illegal construction specifies consecrated property because it does not apply to public buildings. According to Ulpian, illegal construction on 
public property only needs to be demolished if it "obstructs public use," but in the case of sacred property it has to be demolished regardless of the circumstances:

If someone builds in a public place and nobody prevents him, he cannot then be compelled to demolish, for fear of ruins disfiguring the city and because the interdict is for prohibition, not restitution. But if his building obstructs public use, it must certainly be demolished by the official in charge of public works. If it does not, he must impose a solarium (ground-rent) on it. [ . . . The case of sacred places is different. In a sacred place, we are not only forbidden to do anything but also are ordered to make restitution: this on account of religion. ${ }^{24}$

In Justinian's Institutes, prohibitory interdicts regarding res sacrae are likewise mentioned in two passages. ${ }^{25}$

Justinian's Institutes further protected res sacrae by guaranteeing bequests and even payments made to churches in error. Those who withheld things left "by way of legacy or trust to the holy churches and other places of veneration" would pay double the damages. ${ }^{26}$ Payments made in error to the churches were not recoverable. ${ }^{27}$ In these ways, students of law were taught to maintain sacred things through their inalienability and, in fact, when possible, to increase the assets of churches.

The rationale for one of Justinian's laws preventing the diminution of bequests made to churches explicitly refers to the concept that churches were under the eternal protection of God:

For to every man there is one course of life given him by his Maker, the end of which is always death: but it is impossible to set an end to the holy houses and their congregations; they are eternal, under the protection of God. As long as the holy houses endure (and they will endure for all time and till the end of the ages, as long as the name of Christians is among men adored), then righteously shall also the fortunes or revenues, bequeathed to them forever, remain undying, ever serving unceasing pious acts. ${ }^{28}$

The purpose of legislation was to ensure that sacred places remained under God's perpetual protection. On the basis of their eternal protection, such places would also extend perpetual protection to others by means of "pious acts." ${ }^{29}$

One legal and, to some extent, canonical mechanism used to propagate the notion of churches as protected places was to regulate the acquisition of ecclesial property and ensure the increase of assets in three main ways. In the first place, laws and canons added measures to support the reception of gifts (such as allowing ecclesiastical administrators an extended prescriptive period for legal action). ${ }^{30}$ In the second place, laws and canons made churches the recipients of fines and other assets (such as the property of intestate clerics) that would otherwise accrue to civil institutions like the fisc or the imperial treasury. ${ }^{31}$ In the third place, laws of Justinian protected churches from two specific ways of losing assets (receiving liabilities and being shortchanged in the receipt of bequests). ${ }^{32}$ 
Another, even more significant mechanism for constructing churches as protected spaces highly restricted the types of transactions for which ecclesial property could be used as currency, and it is this mechanism that I detail in what follows. I review the many laws and canons (1) forbidding or restricting the possibilities of alienating, loaning, detaining, or leasing ecclesial property, and (2) outlawing acts of violence against or on church property. As in the previous chapter, I cite penalty schedules whenever possible, since they indicate the perceived severity of infractions.

In the matter of alienation, bishops already treated ecclesial property as inalienable before laws did. However, this does not necessarily mean that ecclesial property initially was not considered legally inalienable. Both laws and canons were issued in response to specific circumstances, not as preemptive preventative measures.

\section{RULES ON ALIENATION}

What exactly counted as res sacrae? All consecrated ecclesial property, immovable (i.e., buildings, fields, etc.), movable (i.e., vessels, vestments, etc.), and self-moving (i.e., slaves) counted as res sacrae. Only the revenue produced (e.g., from vineyards) did not count. Excerpts from the writings of second- and third-century Roman jurists in the Digest emphasize inalienability (i.e., unexchangeability in any transaction) as the most salient characteristic of the objects that fall within the legal category of res sacrae. This section reviews canons and laws that address the same issue. As the following rules show, although all ecclesial property was considered res sacrae, exceptions to the prohibition on alienation were regularly made on a case-by-case basis.

Early fifth-century canons applied the principle of inalienability to ecclesial property. In principle, ecclesial property could not be alienated or usucapted, but any alienation that did occur had to be done by the bishop with the consent of the synod or the primate. Some canons targeted clerics who claimed ownership of ecclesial property on account of long, uncontested use (usucaption). Others were directed toward episcopal kin, so as to protect ecclesial property from conflation with personal property.

As for the laws, early and mid-fifth-century constitutions forbade the alienation of ecclesial property to non-Christians and heretics. It was not until 470 that a piece of legislation reiterated the breadth of the principle of inalienability found in the writings of classical jurists collected in the Digest. At the turn of the sixth century, Anastasius permitted alienation under specific circumstances. Justinian both repealed Anastasius's law and promulgated several laws to identify churches as inalienable res sacrae. A number of laws protected sacred things from alienation to such an extent that severe penalties were not only imposed on violators; informers were explicitly permitted to report violations without fear of defamation. 


\section{Canons and Laws on the Inalienability of Church Property}

The first extant canon to ban the alienation of ecclesial property was composed at the Council of Carthage in $419 .{ }^{33}$ Exception was made to "useless" property (property on which taxes had to be paid, but no revenue could be produced).

By contrast, the two earliest extant laws that address the alienation of ecclesial property do not forbid their alienation altogether but address the issue of their alienation to non-Christians and nonorthodox Christians. A constitution of Theodosius II in 423 suggests that consecrated churches were inalienable and could not be returned to their former legal status. ${ }^{34}$ The law explains that since it is impossible to return to the Jews synagogues that had been converted into churches or vessels consecrated to church use, Christians must compensate Jews with places in lieu of the synagogues and money in lieu of the vessels. ${ }^{35}$ This law assumes what later laws would reassert: that ecclesial property could not be alienated to non-Christians. It does not concern the possibility of alienating property to other Christians. Leo legislated in 466 that churches could not be alienated to heretics. According to the law, "estates, properties, and immovable property, where churches or chapels of the orthodox faith are located" cannot be alienated, not even by a last will, to a heretic or anyone opposed to the orthodox faith. ${ }^{36}$ If such alienation occurs, then the lands or possessions are confiscated to the fisc. Since the two laws exist only as excerpts included in the Theodosian or Justinianic Codex, it is impossible to know whether the full text of either law cited a more general principle against the alienation of churches.

It is not until a piece of legislation issued by Leo and Anthemius in 470 that the principle of inalienability is described in the clearest terms. It does not include any exemption clauses as the canons at the Council of Carthage did in 419 and the Council of Agde would in 506. The justification of the law reads as follows:

For it is proper that what belongs to the Most Blessed Church or is acquired hereafter should reverently be kept intact just like the Sacrosanct and Holy Church itself, so that just as the Church is the eternal mother of religion and faith, so her property should perpetually be kept unscathed. ${ }^{37}$

The imperial consistory draws an analogy here between the church as a person and a thing. Since as a person (the church personified as mother of the faith), the church is eternal, so also as a thing (ecclesial property), it should remain perpetual. The law forbids any archbishop or steward from alienating any church property received as a donation or as an inheritance, not even if all the clergy, the bishop, and the steward agree to the alienation. Anyone who attempted to acquire ecclesial property would lose all the gains, which, along with any bribes, would accrue to the church. Such property would have to be reclaimed as though no transaction had occurred at all. The officeholders implicated in the transaction would suffer the following penalties. The steward who allowed such an alienation to occur would lose the stewardship and would have to make restitution for any losses the 
church would incur from his own property. His death would not terminate the case nor would it render his transactions inactionable, because his heirs could be sued. The notary would be exiled. The judges or recordkeepers would lose their rank and all their property.

Anastasius, sometime during his tenure from 491 to 518, published a law that allowed for the alienation of immovable and movable ecclesial property under specific circumstances. ${ }^{38}$ Immovable property and rights to the grain supply were inalienable, except for the discharge of debts, for profit, for the acquisition of more profitable property, for renovation, or for maintenance. Essentially, alienation was only permissible if the immovable property brought loss, not gain, and there was no movable property (aside from the sacred vessels) that could meet the expenses. For the alienation to be valid, the reason for it had to be declared under oath on the Holy Scriptures before the master of the census for Byzantium, the defenders for the provinces, and in the presence of the stewards and clerics of the church. The master of the census or the defender had to render his services free of charge, otherwise he would incur a fine of twenty pounds of gold. If any formalities were omitted, the alienation would be invalid.

It was Justinian who promulgated comprehensive laws concerning res sacrae. He included all pious houses (not only churches, but also hospitals, hospices, orphanages, and monasteries) under the category of res sacrae. ${ }^{39}$ Justinian expresses the principle of inalienability most succinctly in a law sent in 529: "what is under divine law is not bound to human restraints" (quae iuris divini sunt, humanis nexibus non illigari). ${ }^{40}$ Novel 7 of 535 was the first attempt at comprehensive legislation. It directly responded to the law of Leo and Anthemius and that of Anastasius discussed above. Novel 120 of 544 was the second attempt.

Prior to issuing comprehensive legislation regarding sacred things and alienation, Justinian issued two laws: one pertains to the alienation of donations or bequests; the other concerns alienation for the purpose of amassing funds to redeem captives. Justinian issued the first in 528 to the praetorian prefect of the East, Atarbius. ${ }^{41}$ Though Justinian did not outlaw alienation altogether, he forbade those alienations that did not fulfill the overall purpose of donations and bequests. Donated or bequeathed property could not be alienated or diverted for the purpose of the administrator's own profit. If stewards damaged ecclesial property or converted it to their own benefit, they had to restore it. As in the case of Leo and Anthemius's law, the steward's death did not terminate the case. If a steward died before rendering an annual account, his heirs would be subject to audit and would be responsible for making restitution. The law permitted informers. The second law, issued in 529, stated the only circumstance under which particular pieces of ecclesial property could be alienated. ${ }^{42}$ Pieces of movable property-namely, sacred and holy vessels or vestments or other votive offerings necessary for divine worship_could be sold, mortgaged, or pledged only for the ransom of captives. If they should be alienated for any other reason, 
bishops, stewards, and guardians had the right of recovery, while those who took them had no right of action.

After the publication of the Codex, Justinian had a law composed that was both comprehensive in scope and application. ${ }^{43}$ In 535 , he cited the inadequacies of two previous laws (that of Leo and Anthemius for having limited applicability and that of Anastasius for being imperfect) before establishing a comprehensive corrective. The law was sent to all archbishops and two praetorian prefects (John, prefect of the East, and Dominicus, prefect of Illyricum). They were not to permit the alienation of the immovable property of any church anywhere or its deliverance to a creditor by special hypothecation. Immovable property expressly included, "houses, farmlands, market gardens or anything of the kind at all, [ . . ] any agricultural slave or any civic allowance" and ruins, even if the ruins were utterly dilapidated (i.e., had no recoverable buildings or building materials). ${ }^{44}$ Alienation encompassed sale, gift, exchange, and emphyteusis in perpetuity. Monasteries "in which an altar has been consecrated" could not be alienated and transferred "into the form of a private dwelling." ${ }^{5}$ The penalty for alienation was that which was alienated plus its equal value and right of action against the personal property of the steward who alienated the property. The quaestor and magistrates could be fined fifty pounds of gold. The law protected informers: "Such a person will escape the appellation of vexatious litigant; he will be praised for exposing an illegal act, and for being the cause of pious assistance to holy houses." ${ }^{46}$ When Justinian took control over North Africa, he extended the applicability of the comprehensive law to North Africa. ${ }^{47}$

Two exceptions were made. One reiterated the law of 529 pertaining to movable property, in stating that holy vases could not be alienated at all except to redeem captives. ${ }^{48}$ The other was significant in that it acknowledged imperial power over sacred things. The law permitted the emperor alone to exchange property with the churches, provided that he donated to them property of equal or better value than that which he took. The justification for imperial exception reads as follows: "For priesthood and sovereignty are not much different from one another, nor are sacred things from common and public things, inasmuch as wealth and structures are given to the most holy churches from continuous munificence on the part of the emperor." ${ }^{49}$ Recall that Ulpian's schema for the division of things acknowledged a relationship between sacred things and offices of the state. Here Justinian reiterates Ulpian's perspective to justify a special imperial privilege vis-à-vis res sacrae. ${ }^{50}$

Four ensuing laws emended Novel 7 before a new comprehensive law, Novel 120, was issued in 544. The four amendments, respectively, made a further qualification to the principle of inalienability, extended the imperial right of exchange, addressed abuse of the emperor's power of exchange, and defined the metropolitan's role in the alienation of ecclesial property. They were issued over the course of three years. The first of the four amendments (issued in 536) allowed immovable ecclesial property to be alienated for the purpose of paying taxes. ${ }^{51}$ If a debt was 
owed to the fisc and the fisc could not receive immovable property in payment, the immovable property could be sold for money to pay the debt. However, Hagia Sophia and its associated monasteries were excluded from the law's application. The next two amendments, both issued in 537, addressed the issue of exchange. One granted the imperial right of exchange also to all pious houses. ${ }^{52}$ Exchanges could be made not only between the emperor and pious houses, but between one pious house and another. Property could be exchanged between pious houses without an imperial order, provided that an oath was sworn to the effect that the exchange benefited both parties. The other addressed abuse of the imperial right of exchange in Constantinople, showing that even imperially exchanged ecclesial property retained inalienable status. ${ }^{53}$ The abuse in question took the following form: the emperor would exchange ecclesial property and give ownership of what came into his possession to a private person. To prevent exchanged ecclesial property from falling into private ownership, Justinian legislated that if property were to be exchanged with the emperor, then the emperor would retain ownership of it and it could not pass to private persons. If such a series of transactions nevertheless did occur, the steward of the church could reclaim the exchanged ecclesial property. The last amendment, issued in 538, concerned the role of the metropolitan bishop in alienations. ${ }^{54}$ The metropolitan's presence was required for the alienation of any ecclesial property. If the metropolitan himself wished to alienate ecclesial property, then he had to do so in the presence of two bishops of his choice.

In 544, Justinian once again had a comprehensive law composed regarding the alienation of ecclesial property. ${ }^{55}$ Ecclesial property was not to be alienated, except under the following circumstances. For the payment of debts, first movable property was to be used, and then immovable property as a last resort. To prevent churches in the provinces from retaining unprofitable land, the law permitted venerable houses in the provinces to alienate nonincome producing property. For the redemption of captives, the churches of Odessus and Tomis on the Black Sea could alienate immovable property, unless the property were expressly given on the condition that it would not be alienated. Holy vessels anywhere could not be sold or pledged except for the redemption of captives. If there were many vessels and the house was burdened by debts and there was no other movable property that could be used to pay the debt, then they could either sell the holy vessels to venerable places that needed them or melt them down and sell them. The churches of Jerusalem could sell the houses belonging to them for the purpose of purchasing another and better income, but the price of the property was not to be any less than what was collected as rental from it for fifty years.

The last extant law that Justinian issued regarding the alienation of ecclesial property returned to the same issue as the first two extant laws. Theodosius II and Leo had issued laws regarding the alienation of ecclesial property to Jews and heretics, respectively. Like Leo in 466 , Justinian in 545 ruled that ecclesial property could not be alienated to heretics. ${ }^{56}$ If it nevertheless happened, the heretic would 
lose the price and the property, and the steward or officeholder who effected the transaction would be removed from his post, exiled to a monastery, and denied communion for a year.

Gallic, Spanish, and North African councils throughout the sixth century also forbade the alienation of ecclesial property except under specific circumstances. Unlike Justinian, they did not even permit kings the right of alienation. The first extant Gallic canon regarding alienation of ecclesial property, composed in Agde in 506, banned the alienation of ecclesial property, citing the following reason: it is the property of the poor (res pauperes) ${ }^{57}$ Like the canon issued at Carthage in 419 , it contains an exemption clause: in cases of necessity, a bishop could alienate ecclesial property, provided that he had the approval of two or three colleagues. Another canon of the same council denied presbyters and other clerics the right to alienate ecclesial property (res ecclesiae), even the property that they held in usufruct. ${ }^{58}$ If they nevertheless did so, the transaction would be invalid, they would have to return the property to the church, and they would be excommunicated. The first canon that cites consecration as the reason for the inalienability of ecclesial property is known as Ps-Agde canon 49 because in some collections it has been transmitted among a number of canons appended to the canons of the Council of Agde in 506. Administrators were not allowed to exchange, sell, or donate ecclesial property because they were "things considered consecrated to God" (res sacratae Deo esse noscuntur). Gifts of ecclesial property could not even be made to rulers, according to a council of Clermont in $535 .{ }^{59}$ Like many Gallic canons, the canon written at Clermont declared such transactions tantamount to stealing from the poor. Toward the end of the sixth century, the Third Council of Toledo held in 589 reiterated the fact that bishops ought not alienate ecclesial property. ${ }^{60}$

The synod gathered at Orleans in 538 specified temporary excommunication as a penalty for the alienation of ecclesial property. ${ }^{61}$ The excommunication would be lifted once return of the property was made. A council at Paris held sometime between 556 and 573 further specified that no bishop could receive someone excommunicated by another bishop for seizing ecclesial property. ${ }^{62}$

Later councils held in Orleans added that the principle of alienation applied also to ecclesial donations, as did the penalty of excommunication. In 541, the synod ruled that donations made to a parish could not be recalled or alienated without the bishop's written consent. ${ }^{63}$ In 549, the synod stated that donations could not be sold; if one sold them, he or she would be excommunicated and considered a "murderer of the poor." 4

Whereas the only extant law that permits churches to exchange property with one another is Justinian's Novel 54 issued in 537, a council at Hippo issued a canon already more than a century earlier permitting the same thing and a Spanish council at the end of the sixth century also allowed for the conversion of a church into a monastery. The Synod of Hippo in 427 allowed ecclesial property to be exchanged or donated between one church and another. ${ }^{65}$ The canon does not require an 
oath, as Justinian's Novel 54 does. The Spanish council convened at Toledo in 589 allowed bishops to convert one pious house into another. With synodal consent, a bishop could convert a parish church into a monastery. ${ }^{66}$

When Gallic civic boundaries became significantly unstable during the wars between Frankish kings, canons addressed the problem of alienation of ecclesial property in no uncertain terms. While Justinian's Novel 7 issued in 535 explicitly reserved the right of exchange to the emperor, the first canon of the Council of Paris held between 556 and 573 decided that ecclesial property was not bound to civic boundaries and could not be sold or donated even by kings. Under Justinian, however, the latter was an explicit prerogative of the emperor, provided he made restitution of greater value. At Tours, a council held in 567 ruled that anyone who stole ecclesial property and refused to return it after three written requests would be declared a murderer of the poor by a procession of all the clergy reciting Psalm 108 (LXX) and that even those who associated with such a person were to be excommunicated. ${ }^{67}$ Curses were the most severe penalty that could be imposed, more severe even than that of excommunication. While the latter is a communal act of estrangement, the former ritualizes the estrangement through chanted censure and threat. Christian interpretations of Psalm 108 identify Judas as the subject of the psalm's maledictions. ${ }^{68}$ By virtue of chanting such a psalm in procession, the clergy ritually project the condemnation of Judas onto the offender. ${ }^{69}$ Canon 26 of the same council refers to ecclesial property as "things of God" (res Dei) and adds that the possession of ecclesial property on the pretext of "protecting it" was no excuse for theft. Still further canons discussed below addressed the problem of alienation in terms of theft.

Civil laws concerned two particular issues-namely, who could not be the recipient of alienated ecclesial property (Jews and heretics) and under which specific circumstances ecclesial property could be lawfully alienated. Canons raised a number of other concerns as well, as the following section shows.

\section{Exceptions to the Rule and Protections against Illegal Alienation}

Important to bishops' meetings were questions such as how a canonical alienation might take place and how to protect ecclesial property from administrators' families and from theft, especially during vulnerable times such as the vacancy of an episcopal seat.

Alienation by Bequest or Donation. In addition to the canons and laws cited above that claim as ecclesial property all the possessions that clerics acquire after their ordination, canons and laws also expressly forbade clerics from bequeathing ecclesial property to anyone. Canon 5 for the Council of Hippo in 427 addressed the question of whether clerics might bequeath to kin property they acquired in their own name after their ordination. The assembled bishops decided that such property would belong to the church and therefore clerics could not bequeath it 
to relatives. If they nevertheless did so, they dishonored the church and would be judged by the synod. It is not until Justinian a century later that a law expresses the same rule. It pertains only to bishops, however, not to all ecclesiastical administrators. Justinian's law of 528 discussed above already regarded as ecclesial property all that bishops acquired after their ordination..$^{70}$ In 545, Justinian set forth regulations regarding bishops' bequests. ${ }^{71}$ Bishops could not donate or bequeath movable, immovable, and self-moving property (i.e., slaves) that they acquired during their episcopacy to their relatives or any other person, unless it belonged to them prior to their ordination or they inherited it from their relatives up to the fourth degree.

Several sixth-century canons from Gaul concern the same issue. The alienation of ecclesial property in the form of a bequest was simply out of the question, but some regions allowed bishops the same prerogative of exchange that Justinian had reserved for the emperor alone. Such canons require the bishop to indemnify the church for any property alienated. The Council of Agde in 506 decided that bishops could not bequeath even ecclesial property that they used for themselves. ${ }^{72}$ On the contrary, the Council of Epaon in 517 allowed bishops to bequeath ecclesial property so long as they donated to the church something of the same worth from their private belongings. ${ }^{73}$ Such a canon granted bishops the same right of exchange that Justinian reserved for the emperor alone. ${ }^{74}$ Even Justinian's extension of the prerogative to exchanges between pious houses, however, did not allow an administrator's private property to supplant ecclesial property. ${ }^{75}$ Likewise, the Fourth Council of Orleans, held in 541, required bishops to bequeath to the church the equal value of what they mortgaged, financially burdened, or sold of ecclesial property. ${ }^{76}$ If they failed to do so, then the responsibility would fall on the heirs of the former ecclesial property to compensate the church. The council listed one exception: the bishops' freedmen could not be reenslaved for this purpose. That is to say, ecclesial freedmen could not be offered to a church as slaves to reimburse alienated property.

Alienation by Usucaption. Aside from donations in life or death, property could also be acquired through usucaption, the long unquestioned use of property. Typically, the legal prescription period for usucapio was thirty years. Two sixth-century Gallic canons did not permit the laws of usucaption to transfer ownership of property from the church to another party, but a fifth-century canon did allow the prescription period to resolve jurisdictional problems. The Council of Chalcedon in 451 allowed bishops to retain possession of countryside and village parishes that they held uncontested for thirty years; any disputes that arose before thirty years had elapsed were to be resolved by the provincial synod. ${ }^{77}$ The Council of Orleans in 511 explicitly denied that civil laws of usucaption could apply to ecclesial properties. $^{78}$ Any lands or vineyards that an ecclesiastical administrator allowed another to use belonged to the church, regardless of how long the person used it. At Epaon 
six years later, in 517, a council forbade clerics the usucaption of ecclesial property even if the king willed it. ${ }^{79}$ The canons of Orleans and Epaon demonstrate that bishops of Gaul explicitly denied not only the application of a civil law to churches but, most importantly, the right of kings over ecclesial property. While Justinian reserved imperial right over ecclesial property, he nonetheless agreed that such property should not fall into private ownership even via imperial means. ${ }^{80}$ The decision at Epaon in 517 and that of Justinian twenty years later with Novel 55 address a similar concern. Once a thing becomes sacred, its status cannot change because it is inviolable.

The Bishop's Prerogative in Matters of Alienation. A number of canons from North Africa, Italy, and Gaul emphasize that the bishop is the sole administrator who, under specific circumstances and with the consent and witness of certain other administrators, may alienate ecclesial property. In general, canons state that no lower-ranking clerics may alienate ecclesial property, but there are specific conditions in which it was permitted. The Council of Carthage in 419 drew an analogy between the role of the presbyters relative to the bishops and that of the bishops relative to the synod. Presbyters could not dispose of the property of the church (res ecclesiae) without the consent of their bishop, just as bishops could not dispose of church property (praedia ecclesiae) without the consent of the synod or his presbyters. ${ }^{81}$ Except in cases of necessity, even the bishop could not dispose of things from the endowment of the church (res tituli). At a council in Rome in 502, over which Pope Symmachus presided, it was specifically decreed that laypersons might not regulate ecclesial property, and the council anathematized clerics who signed their names on deeds that alienated ecclesial property. ${ }^{82}$

Gallic canons describe the consequences presbyters and other lower-ranking clergy would face for alienating ecclesial property. The Council of Epaon in 517 declared sales effected by a presbyter invalid and required that he return the property. ${ }^{83}$ The penalty specified at Orleans about a decade later, in 538 , was more severe. Presbyters and other clerics (including abbots) not only had to return alienated property; they also forfeited their office. ${ }^{84}$ The question of donations to parishes arose in the next council at Orleans in 541; they too were ecclesial property that only the bishop could alienate. ${ }^{85}$

In order for the bishop himself, however, to alienate useless ecclesial property, he needed the consent of his episcopal colleagues. The Council of Carthage in 401 and that of Epaon in 517 required the consent of the primate or metropolitan of the province for any alienation to take place. ${ }^{86}$ Almost two decades later, in 419, the Council of Carthage insisted on a decision of the synod for useless ecclesial property to be sold. ${ }^{87}$

Two canons further require of the bishop that he obtain the consent of the presbyters in his jurisdiction. The canon of the Council of Carthage in 419 that denies 
presbyters the right to alienate ecclesial property implies that bishops only have the right with the consent of not only the synod but of his presbyters as well. ${ }^{88} \mathrm{~A}$ collection of Gallic canons made at the end of the fifth century demands the written permission of the presbyters for a bishop to donate, sell, or alter ecclesial property. ${ }^{89}$

There were, as always, exceptional circumstances under which a bishop did not need the consent of the synod and presbyters and under which even lowerranking clerics could effect a valid alienation. In cases of urgent need, a bishop could alienate ecclesial property, but even so he had to gather together neighboring bishops to witness to the sale, according to the Council of Carthage in $419 .{ }^{90}$ Likewise, the Council of Agde in 506 required the approval of two or three episcopal colleagues even in urgent cases. The same council, however, allowed small, distant patches of land or vineyards to be sold by a bishop in a poor financial situation without consulting other bishops. ${ }^{91}$ The Council of Rome in 595 permitted one condition under which ecclesial slaves could be freed: that they might become monks. ${ }^{92}$ As for the possibility of alienation by nonbishops, the Council of Orleans in 549 determined one scenario in which such a thing would be permissible. ${ }^{93}$ To relieve a great need during a particular kind of episcopal vacancy (in the event that the bishop had been indefinitely recalled and no new bishop had been appointed), lower-ranking clerics could alienate (auferre) ecclesial property.

Legal Suits regarding Ecclesial Property. Sixth-century Gallic canons refer to two types of legal actions: one of a church administrator to reclaim invalidly alienated property and another of any plaintiff who attempted to reclaim personal property unjustly appropriated as ecclesial property. The Council of Epaon in 517 explicitly allowed bishops to make a legal action against uncanonical sales made by abbots. ${ }^{94}$ The Third Council of Orleans in 538 allowed a succeeding bishop to purchase back the property that the former bishop sold within thirty years and excommunicated anyone who refused to sell the property back. ${ }^{95}$ Similarly, the Fourth Council of Orleans in 541 permitted a succeeding bishop to decide whether clerics could retain any ecclesial property they took during the vacancy of the see. ${ }^{96}$ As for plaintiffs who attempted to reclaim their personal property from bishops, the Council of Orleans in 511 decided that they should not be excommunicated on account of taking such legal action, so long as they did not speak abusively or make criminal charges. ${ }^{97}$

Protections against Illegal Alienation. Synods of fifth- and sixth-century Gaul, Spain, and Britain put measures in place to prevent or penalize theft of ecclesial property. Inventory lists or a guard would discourage theft after the death of a bishop; the requirement of episcopal kin to receive their inheritance from the church would prevent them from conflating ecclesial with personal property; and the threat of punishment offered a further means to avert theft. 
Synods at Riez and Lerida set up guards to protect ecclesial property during the vacancy of a see. At Riez in 439, the synod decided that a neighboring bishop should take control of ecclesial property and report to the metropolitan. ${ }^{98}$ The Council of Valencia less than a century later in 529 cited the decisions at Riez to forbid clerics from appropriating ecclesial property after the bishop's death and to require of the neighboring bishop that he draw up an exact inventory of the jurisdiction's property and report to the metropolitan. ${ }^{99}$ Similarly, the Council of Orleans in 533 required, as part of the funeral preparations, that a bishop and his presbyters meet in a house of the church (in unum domum ecclesiae $)^{100}$ to make an inventory of church property (res ecclesiae) in advance and appoint a guard, so that nothing would be stolen in the course of the funeral. ${ }^{101}$ An earlier canon from a Spanish synod at Tarragona in 516 delegated the responsibility for writing an inventory list to local priests and deacons after the funeral if the bishop died intestate. ${ }^{102}$ Likewise, at Lerida in 546 the synod put the episcopal residence of deceased bishops in the custody of a guardian with two faithful assistants to preserve all things until the arrival of the new bishop. ${ }^{103}$ Anyone who violated the rule would be guilty of sacrilege, be anathematized, and suffer peregrine communion (communio peregrina). ${ }^{104}$

A further provision to protect ecclesial property during the vulnerable period of a vacant see was put in place at Valencia in 529. Not only did the synod echo the earlier decision of Riez for the production of an inventory list, but it also required that the bishop's kin request permission from the metropolitan and the bishops of the province before laying claim to their inheritance. ${ }^{105}$

Some of the canons cited above and others too included penalties against those who unjustly acquired ecclesial property. The early fifth-century Synod of North Britain penalized monks with one year of penance and exile for a repeated offense of stealing consecrated things. ${ }^{106}$ The Council of Agde in 506 targeted clerics who stole consecrated things from the church and penalized them with peregrine communion. ${ }^{107}$ The Third, Fourth, and Fifth Councils of Orleans threatened excommunication against any who took ecclesial property and did not return it. In 538, the synod decided that those who took church property (res ecclesiae) and did not return it to the bishop would be excommunicated until the return was made; likewise, those who retained what had been bequeathed to the church or donated were excommunicated until they made restitution. ${ }^{108}$ Similarly, in 541, the council forbade clerics and laity from having ecclesial property without the permission of the bishop. ${ }^{109}$ Possessors of church property were to return the property at the demand of the bishop or the civil judge; those who did not would suffer excommunication until they returned the property and did penance. The council in 549 addressed the problem of bishops, clerics, and laity taking property from churches in other kingdoms. ${ }^{110}$ Such persons would be excommunicated until restitution was made. 


\section{BISHOPS' KIN AND ECCLESIAL PROPERTY}

\section{IN ALEXANDRIA AND EDESSA}

Ecclesial properties were sacred things that could not be alienated, and bishops' relatives were not exempt from the rule. Canons from the Councils of Antioch in 328, Carthage in 419, and Hippo in 427 underscore this point. ${ }^{111}$ Kinship to the bishop did not entitle a person to any privileges or benefits. This legal and canonical context offers a lens for evaluating certain charges leveled against Ibas of Edessa and Dioscorus of Alexandria, as well as certain canons composed as a result of their trials. As for Ibas of Edessa, several clerics charged him with sacrilege against ecclesial property. In the end, Ibas's trials led to the creation of a new administrative post in every diocese for the safeguarding of sacred things. As for Dioscorus of Alexandria, a certain presbyter named Athanasius complained about his administrative conduct. Athanasius appealed legal actions that Dioscorus took actually to safeguard ecclesial property. The presbyter Athanasius's appeal was ignored; in fact, the council issued a canon to protect sacred things from clerics like him.

Before examining Ibas's and Dioscorus's cases in detail, it is important to note the nature of conciliar acts as sources. ${ }^{112}$ To do so, it will be helpful to imagine a scene at one of Ibas's trials. It is the year 448 . A council has gathered. Bishop Ibas of Edessa stands trial. Bishop Photius of Tyre presides as the main judge. Four of Ibas's clerics have accused him on many counts, including sacrilege. Photius responds to the clerics' plaint (their list of charges) by asking them to prioritize the charges. Photius says:

First select and begin with the things that are by general agreement forbidden by both the canons and the laws and are clearly hateful to those who fear God. It is the following points that we think crucial: first, that he who has been appointed to the priesthood must be of sound faith, then that he be free from all depravity, but also that he should not betray piety especially for the sake of money. ${ }^{113}$

Photius lists the most egregious things a bishop could do to merit a trial. In general, a bishop could violate imperial laws, ecclesiastical canons, or both. Photius then goes on to describe two kinds of violations that are especially egregious and that are forbidden by laws and canons alike: preaching unsound faith and practicing immoral conduct, especially administrative financial misconduct, or, to quote Photius's words again, "betray[al] of piety especially for the sake of money." Photius gives voice here to the significance of administrative financial misconduct.

However, the acts of councils usually do not record proceedings pertaining to misconduct, preferring to settle them orally. ${ }^{114}$ Conciliar acts are not verbatim transcripts of all that was said or read aloud at sessions. Instead, synods made motions to have parts of the proceedings recorded. For example, at Ibas's third trial, a presbyter gave an address to the synod, and the synod then motioned for 
the presbyter's account to be recorded in the acts. Why? The presbyter's account concerned matters of faith:

The holy synod cried out: "We request that that may be stated in writing. That relates to the faith. Let it be stated in writing. It is directed against Christ. It ought to be put in writing." 115

Transcripts of trials focus on discussions of faith, so they leave little room for historians to trace the importance of administrative financial misconduct. ${ }^{116}$ Instead, the tracings can be found in three other places: the legal context of ecclesial property, the charges leveled by plaintiffs as recorded in retrials, and the canons issued at the end of conciliar gatherings.

Ibas of Edessa was tried four times between the years 448 and 451. At the first trial in Antioch, he was acquitted; at the second in Tyre and Berytus, he was disciplined; at the third in Ephesus, he was deposed; and at the fourth in Chalcedon, he was reinstated with discipline. ${ }^{117}$ Charges of misconduct were leveled at all the trials, but they have only been transmitted to us because they were recorded in the third and fourth trials. The first trial took place in Antioch, where Domnus of Antioch presided. Ibas had excommunicated four of his presbyters, Samuel, Cyrus, Maras, and Eulogius, so as to prevent them from being canonical plaintiffs, ${ }^{118}$ and only the latter two appeared before Domnus. ${ }^{119}$ The former two went directly to Constantinople, for which reason Domnus not only excommunicated but deposed them. Since one of the charges was sacrilege, the plaintiffs expected that Ibas could be deposed on that count alone. Domnus, the judge, said, however, that "it was in [Ibas's] administrative power to act as he did." ${ }^{20}$ According to the charge of sacrilege, Ibas melted down two hundred pounds of sacred silver vessels to amass funds to free monks and nuns from their captivity among Arabs. He received more than enough money from the treasurer but melted the vessels anyway. Justinian would allow vessels to be melted for the ransom of captives about one century later, ${ }^{121}$ but we do not have any earlier laws or canons that address this issue. ${ }^{122}$ The plaintiffs considered the deed sacrilege, but the judge decided that Ibas did not violate his administrative role.

The same plaintiffs appealed Domnus's decision before the Synod of Constantinople at the Church of the Holy John. There they raised the charges pertaining to the faith, and the emperor appointed the bishops Photius of Tyre, Eustathius of Berytus, and Uranius of Hemerium to hear the case at a second trial. The plaint that the four presbyters submitted to Photius of Tyre, Eustathius of Berytus, and Uranius of Hemerium is recorded in the Acts of the Council of Chalcedon. It includes the following seven charges that pertain to ecclesial property:

1. Ibas did not redeem captives (ad redemptionem captiuorum) with the full sum of money he received for this purpose. In fact, he melted down consecrated silver vessels (uasis argenti sacri) to amass funds he did not spend. 
2. Ibas did not place a donated jeweled chalice (calicem gemmatum) in the church treasury (inter uasa sanctae ecclesiae).

6. Ibas alienated ecclesial revenue (omnes ecclesiasticos reditus) to his brother and nephews. Ibas alienated bequests and donations (hereditates et munera), including dedicated gold and silver crosses (cruces positas aureas et argenteas), to his brother and nephews. Ibas alienated the welfare of prisoners (expensa carcerum) to his relatives' households.

10. Ibas prevented the presbyter Pirozus from bequeathing his property to churches that had no revenue (ecclesiis relinquente reditus nullos habentibus).

11. Ibas did not prevent Bishop Daniel (his nephew) from bequeathing ecclesial property (facultatem et praedia ex ecclesiasticis rebus) to Challoa and her children. Challoa misused ecclesial property (multis rebus ecclesiasticis abutens) she had in usufruct by lending money at interest.

12. Abramius, a deacon and apantetes, bequeathed ecclesial property (nostra ecclesia multas et innumeras res habuit, quae pro ueritate erant nostrae ecclesiae) to Bishop Daniel, who in turn donated it to Challoa.

14. People cut wood from the ecclesial property of Edessa and used it to build on Challoa's estates (ex ecclesiae Edessenae praedio Lafargaritas siluas caedentes portauerunt ad praedia Challoae). ${ }^{123}$

In sum, the four presbyters accused Ibas of alienation of ecclesial property, obstruction of a bequest to the church, and failure to protect or reclaim ecclesial property misused by his nephew the bishop Daniel, Challoa, deacon and apantetes Abramius, and unnamed woodcutters. On February 25, 449, the bishops Photius of Tyre, Eustathius of Berytus, and Uranius of Hemerium reported on the hearing at which they reconciled Ibas of Edessa to his four presbyter-plaintiffs (Samuel, Cyrus, Maras, and Eulogius).

Less than two months later, Chaereas the count and judge of Osrhoene would hear the complaints of the people, archimandrites, and monks of Edessa against Ibas in the martyrium of the Holy Zachaeus on April 12, 449. ${ }^{124}$ One of the recorded acclamations reads, "Let what belongs to the Church be restored to the Church." 125 Two days later, the same or a similar group of people approached Chaereas at the council chamber and uttered more specific acclamations: "Ibas melted down the Service of (Plate belonging to) the Church," "Ibas has plundered many Churches: the goods of the Church he now sells," "The possessions (of the Church) are ever such-Daniel and Challoa have consumed them (in pleasure). The City is ruined because of Ibas." 126

Chaereas submitted a report to the consul Protogenes and the eparchs Albinus and Salimon, in which he described the hearings at the martyrium and council chamber and appended the petition and oath he received from Micallus, presbyter of the church of Edessa, signed by all the plaintiffs. The petition explains that the plaintiffs tried to render Ibas the honor due to a bishop, despite his 
maladministration of ecclesial property. Once matters regarding his faith arose, they decided that they could no longer accept him as their bishop:

Although his [Ibas's] reputation had become sadly sullied by reason of his (mal-) administration of the property (the treasure) belonging to the Holy Church, as well as on other accounts, yet even then we still continued in this way to pay him honour, until, grievous charges being urged against him, he was arraigned on matters, relating to the Orthodox Faith. ${ }^{127}$

The petition quoted the following acclamations: "He has sold the Holy Thomashe has plundered the Holy Church-he gave the possessions of the poor to his relatives"; "This man oppressed the poor. This man pillaged (made spoil of) the Church-he secreted (or appropriated to himself) the Holy Vessels-he made use of the Holy Vessels for his own purposes." 128 Ten presbyters, twenty deacons, nine subdeacons, and eleven monks signed the petition and swore the oath.

Chaereas also submitted a report to Martialis, the count and master of divine offices. It included the minutes of a hearing at which Count Theodosius was present. The latter asked Chaereas to bring an end to the tumults that arose on account of Ibas's "many acts subversive of the laws and adverse to the Christian faith."129 Chaereas asked all those who signed the petition to come forward and confirm that they had submitted it. Then he asked the presbyters among them to state their indictment. Presbyter Samuel referred to Ibas's "habit of everywhere scattering gold abroad for the condemnation of the truth." 130

Only charge number 8 in the four presbyters' plaint accused Ibas of unsound faith, but it is the one on which the minutes of Ibas's third (Ephesus 449) and fourth (Chalcedon 451) trials focus. Ibas was deposed at his third trial in Ephesus on the basis of that charge alone (or perhaps also in addition to the charge of sacrilege). He was rehabilitated at his fourth trial in Chalcedon on the basis of his exoneration from that charge. As part of the terms of reconciliation, Ibas promised to appoint a steward from among the clergy to administer ecclesial property and revenue.

The Council of Chalcedon issued canon 26 in response to the problems raised by Ibas and his nephew Daniel's administrative misconduct. ${ }^{131}$ It codified into a general rule what the bishops Photius of Tyre, Eustathius of Berytus, and Uranius of Hemerium had required of Ibas so as to reconcile him to his clerical plaintiffs in 449: the appointment of an oeconomus to manage the property of the church of Edessa as was the rule in Antioch. ${ }^{132}$ The Council of Chalcedon undid the act of deposition at Ephesus in 449 and reverted to the disciplinary decision of the second trial by issuing a canon. The twenty-sixth canon of the Council of Chalcedon generalized the discipline imposed on Ibas into a rule that all churches had to follow. The canon obliged every bishop to administrate ecclesial property through an appointed oeconomus. ${ }^{133}$ In other words, Ibas's case led to translocal reorganization of ecclesial property administration. It would become the duty of a new staff 
member, each bishop's deputy administrator or oeconomus, to prevent misconduct and ensure that sacred things were treated as sacred things.

Dioscorus of Alexandria was also tried at Chalcedon. One of the plaintiffs was his predecessor Cyril's nephew, the presbyter Athanasius. Athanasius reacted against the ways in which Dioscorus asserted the rights of the church over its properties, and he presented the most detailed plaint against Dioscorus. A legal debacle can be reconstructed from this plaint. Athanasius began by describing the will of his uncle, Cyril, Dioscorus's episcopal predecessor:

In the will he [Cyril] made when about to die he honoured his successor as bishop, whoever that might be, with many large legacies from his own estate, adjuring him in writing, by the venerable and awesome mysteries, to comfort his family and not to cause it any trouble. ${ }^{134}$

This statement suggests that Cyril's relatives held ecclesial properties. Cyril bequeathed his future successor a gift so that his relatives might benefit from ecclesial property after his death. ${ }^{135}$

On the basis of Athanasius's plaint and the legal-canonical context, I reconstruct the legal battle as follows. Dioscorus took legal action to reclaim ecclesial property from Cyril's kin. He demanded houses, adjoining buildings, porches, and the revenue that had accrued from the properties. When the family refused, Dioscorus confiscated the property, converted the houses into churches, and exiled the family. Dioscorus sent a report regarding the case to a civil official, the master of the offices. The family appealed to Constantinople, where the civil official upheld Dioscorus's decision and required the family to pay what was due. If the property had been held unlawfully, they would have owed all the gains they accrued during the entire term of its unlawful use. They would also owe any fines imposed for their illegal activity. Athanasius lists enormous amounts of money that the master of the offices required of Athanasius and his kin: 1,40o pounds of gold from Cyril's nephews, eighty-five pounds of gold from Cyril's sisters, and forty pounds of gold from Cyril's grandnephews. ${ }^{136}$

Neither an oral nor a written investigation ensued because Dioscorus refused all three summonses to appear for trial. ${ }^{137}$ Yet the council nevertheless put a measure in place to ensure the sanctity of ecclesial property. The synod ignored Athanasius's appeal and issued a canon that responded directly to the situation. Since the presbyter Athanasius's appeal concerned properties he and his family illegally held after Cyril's death and before Dioscorus's appointment, canon 22 prohibits clerics from taking ecclesial property during the vacancy of a see.

Ibas avoided deposition at the Council of Chalcedon by making a sufficient show of good faith and by agreeing to submit to the disciplinary action the synod imposed. Still, the synod made an extra effort to keep sacred things inviolable. The assembly issued a canon requiring not only Ibas but every bishop to have a deputy assistant for the administration of sacred things. As for Dioscorus, even though 
he refused to appear for trial, the synod nevertheless recognized the judiciousness of his administrative actions. The assembly issued a canon against the presbyter who appealed the actions Dioscorus took to reclaim ecclesial property. The synod wrote a rule specifying that no cleric was entitled to take ecclesial property during the vacancy of a see. Even if a bishop passed the test of faith, as Ibas did, the synod would still issue regulations to ensure proper administration of ecclesial property. Even if a bishop refused to appear for trial, as Dioscorus did, the synod would still compose rules to assert the inviolability of sacred things.

Episcopal trials were not only about theological controversy or sacred faith. The trials were also about sacred things. Photius of Tyre recognized the importance of faith, but he also mentioned conduct, especially financial misconduct. The emperors Leo and Anthemius, as mentioned above, connected the dots between faith and ecclesial property. According to their logic, faith and ecclesial property should be as eternal as the mother church herself. Late antique bishops were not only supposed to defend the faith. They were supposed to defend tangible, sacred things, too. Late antique bishops' administrative duty was to make sacred things as eternal as the faith itself.

\section{RULES ON LOANS, DETENTION, AND LEASE}

\section{Rules on Loans (Hypothecation)}

Whereas alienation resulted in an indefinite loss of ecclesial property, there were also temporary ways in which ecclesial property could be divested. Under Justinian the issue of the hypothecation of ecclesial property in Constantinople arose. Hypothecation was a kind of security deposit: property would be given to the creditor as security for the repayment of a loan. Justinian initially forbade the hypothecation of ecclesial property in a rescript to Bishop Epiphanius of Constantinople in $535 .{ }^{138}$ The penal clause states that the creditor would be deprived of his credit and the creditor could have an action against the person who contracted the loan. Nine years later, in 544, Justinian wrote to the praetorian prefect of the East, Peter, permitting hypothecation of ecclesial property in Constantinople, but he added a condition for loan repayment. ${ }^{139}$ If the bishop, steward, or manager received a loan, it could not be charged to the venerable house, unless they first showed that it went to the use of the venerable house. Otherwise, the creditor had no right of action against the venerable house, but rather against the person or his heirs who received the loan.

\section{Rules on Detention and Lease (Usufruct and Emphyteusis)}

Though ecclesial property could not be alienated, it could be detained (held in usufruct) or leased (held by emphyteusis). Usufruct was a temporary detention of land, by which the usufructuary could make use of the property only for his or her own needs. ${ }^{140}$ The property itself was a res sacra and any revenue that exceeded 
the usufructuary's needs accrued to the church. Emphyteutic leases could be bequeathed over the course of one or two generations, or even permanently ("perpetual emphyteusis"). ${ }^{141}$ Laws and canons ensured that the detained or leased property remained ecclesial property, that detentions or leases were profitable to the church, and that due process was followed by all parties involved.

Usufruct. Of the three extant laws on ecclesial usufruct, two concern the terms of the agreement and one limits the individuals eligible for the detention. The emperors Leo and Anthemius addressed a law in 470 to the praetorian prefect of the East, Armasius, regarding the usufruct of ecclesial property. ${ }^{142}$ Ecclesiastical stewards could grant temporary usufruct of ecclesial property. Once the period agreed on expired or the usufructuary died, twice the amount of returns and the estate with its immovable property, servile tenants, and slaves had to be given to the church. Justinian reiterated the law in a rescript to Bishop Epiphanius of Constantinople in $535 .{ }^{143}$ Ten years later, Justinian restricted the populations eligible for grants of ecclesial usufruct. ${ }^{144}$ In a law addressed to the praetorian prefect of the East, Peter, in 545, Justinian ruled that ecclesial property could not be granted in usufruct to heretics. The penal clause stated that the heretic would lose the price and the property of ecclesial lands that he or she held in usufruct, and the contractor would be removed from his post, exiled to a monastery, and denied communion for a year.

Canons primarily regulated clerics and ecclesial freedmen's usufruct of ecclesial property. At the Council of Agde in 506, the synod permitted bishops to allow freedmen the usufruct of property that did not exceed the value of twenty gold solidi. ${ }^{145}$ Bishops could also allow clerics and others the usufruct of useless ecclesial property. The Council of Toledo in 527 emphasized that the usufruct was not hereditary. ${ }^{146}$ The canon states that once a cleric dies, the usufruct cannot be bequeathed; rather, the land must return to the church. The Council of Lyons in 567 ensured that succeeding bishops would honor the contracts of usufruct granted by their predecessors. ${ }^{147}$ It stressed that any penalties imposed on usufructuaries should affect the person, not the property.

Only one known canon concerned the long-term usufruct of ecclesial property. The Council of Orleans in 541 required that the profits made on a lifetime usufruct of ecclesial property be given to the church, not alienated or given to relatives. ${ }^{148}$

Emphyteusis. Like the lease of imperial property and private property, that of ecclesial property was called "emphyteusis." Justinian issued six laws on the matter of ecclesial emphyteusis, most of which loosened earlier restrictions. One law barred heretics from emphyteusis. Another required clerics to follow due procedure when entering on an emphyteutic agreement.

Around 530, Justinian began to set limits on emphyteutic leases of ecclesial property: restricting who was eligible for the lease and the temporal length of the lease. ${ }^{149}$ Ineligible lessees were the poor, the keepers of the archives, and the 
prefects of the city (even by means of a third party). The penalty for noncompliant stewards was to pay out of their own pocket the same value as the property to be recovered. The penalty for prefects was the same. A fine of twenty pounds of gold applied to both the lessor and the lessee. The reason why property could only be leased to the wealthy was that it had to be restored to its former condition on return. If the property suffered damage, the lessee would be evicted and had to make restitution. As for the temporal length, a church could lease lands for up to twenty years.

In 535, Justinian expanded the temporal length of an ecclesial emphyteutic lease in a rescript to Bishop Epiphanius of Constantinople, but he also shortened the length of the grace period for unpaid rents. ${ }^{150}$ An emphyteutic lease could be bequeathed to two heirs. Instead of the customary three-year grace period for the payment of rents, only a two-year period was granted for emphyteusis of res sacrae. At the end of the grace period, the church could reclaim the land held under emphyteusis. Perpetual emphyteusis (in which there was no limit to the number of generations over which the lease could be inherited) was forbidden; the penal clause lists loss of the property and perpetual payment of what would have been paid as the punishment for violators.

Only two years later, in 537, Justinian began to make exceptions to the rule against perpetual emphyteusis of ecclesial property in a rescript to Bishop Mena of Constantinople. ${ }^{151}$ Such contracts could be made between pious houses, with the exception of Hagia Sophia.

Justinian made a second exception in 544 in a law issued to the praetorian prefect of the East, Peter. ${ }^{152}$ Justinian permitted perpetual emphyteusis of ecclesial property in Constantinople in one case only: sacred ruins, which pious houses were unable to restore. Such places could be leased under perpetual emphyteusis, provided that the rental payment amounted to either a third of the income of the buildings when they were still standing or half the income of the buildings after their restoration. The same law allowed for similar contracts of perpetual emphyteusis in the provinces.

The same law mentioned above that excluded heretics from contracting an ecclesial usufruct excluded them from emphyteusis as well. ${ }^{153}$ Issued in 545 to Peter, the praetorian prefect of the East, the law penalized noncompliant heretics with loss of the price and the property; the contractor would be removed from his post, exiled to a monastery, and denied communion for a year.

Justinian required clerics to follow due process in contracting an emphyteutic lease. A law issued in 546 to the master of the offices, Peter, set forth a fine schedule to be imposed on noncompliant clerics. ${ }^{154}$ If a bishop did not follow due process in leasing ecclesial property through emphyteusis, all his personal property would be confiscated to his church. If it was a steward or other cleric who failed to follow due procedure, then he would owe a pecuniary fine determined by the bishop. ${ }^{155}$ The law added a measure of protection to the church against legal action from 
lessees: anyone who received ecclesial property for the purpose of emphyteusis "[is] to have no action against the church" or any of the administrators. ${ }^{156}$

\section{RULES AGAINST ACTS OF VIOLENCE}

Res sacrae were, as outlined above, protected from several different forms of commercial exchanges. They were also sacred precincts in the sense that they were literally inviolable: no acts of violence could be committed and arms were not even permitted on the premises. Churches were protected from not only exterior commerce but also interior damage.

Multiple laws protected churches from acts of violence (iniuriae) by imposing capital punishment on perpetrators. Honorius, Marcian, and Justinian all named death as the penalty for acts of "outrage" in churches. Leo stressed proper procedure as the course of action one ought to follow rather than committing outrage in churches. One Gallic canon anathematizes those who commit outrage in churches.

Honorius issued the first extant law on outrage against churches in 409 to the praetorian prefect of Italy and Illyricum, Theodorus. ${ }^{157}$ The law instructs that those who commit outrage against a church are guilty of sacrilege and governors in Africa are to punish them with a capital sentence. Members of the municipal council who intentionally overlooked such crimes would suffer confiscation of their property and deportation.

Two laws, one of Marcian and the other of Justinian, and one Gallic canon threatened those who disregarded the safety of churches with severe penalties. In the wake of the Council of Chalcedon, Marcian issued a general constitution exhorting all people to refrain from sedition in the sacrosanct churches and threatening violators with the supreme penalty. ${ }^{158}$ Likewise, Justinian would also name death as the penalty for certain misconduct in churches. In 546, Justinian wrote to the master of the offices, Peter, that those who disrupted the holy mysteries or processions or inflicted harm on clerics in the course of services would suffer capital punishment. ${ }^{159}$ A council held in Paris around 556 anathematized those who exercised violence against ecclesial property. ${ }^{160}$

Two constitutions of Leo that have been transmitted without dates or recipients show his emphasis on due process. One law forbids anyone who has a dispute with anyone to disturb the church; if imperial assistance should be required, he or she should seek the emperor's audience via the archbishop. ${ }^{161}$ Another law indicates that if a disturbance is made in a church, the perpetrator loses his or her cause of action regardless of any protections under the laws; the prefect is to arrest him or her and subject him or her to punishment. ${ }^{162}$

Episcopal synods and imperial consistories alike issued regulations on ecclesial property for the purpose of protecting it. Laws and canons on property damage as well as acquisition, detention, and lease of property demonstrate some of the ways in which such a general principle took shape in specific contexts. Above all, 
regulatory practices on the matter of alienation reveal the extent to which ecclesial property received special legal and canonical protections. Ecclesial property could not be alienated, but in the event that the alienation of certain goods or lands became advantageous or even necessary for the overall increase of ecclesial assets, exceptions could be made. Even so, episcopal synods would name procedural requirements, such as the assent of multiple bishops to the alienation, to prevent misconduct and safeguard the protection of ecclesial property. The case study below highlights how a specific kind of legal document, the dying bishops' will, could play a role in the protection of ecclesial property.

\section{A CIVIL AND ECCLESIASTICAL TUG OF WAR IN ROME}

Symmachus of Rome countered the claims of his episcopal rival Laurentius in the beginning of the sixth century. To do so, Symmachus adopted the opposite strategy to that of the North African bishops described in chapter 1. Whereas the bishops of North Africa endorsed civil regulation to confront their rivals, Symmachus rejected civil rule-making pertaining to ecclesial property. While Laurentius was alive, Theodoric, the Ostrogothic king of Italy from 493 to 526, assisted Symmachus's cause. ${ }^{163}$ Later, however, the same king would reject a conciliar decree against civil law that Symmachus promulgated. As we saw in chapter 1, ecclesiastical authorities in the fifth century actively petitioned for civil enforcement and regulation of ecclesiastical affairs. To defend himself against Laurentius's charges, Symmachus argued that there should no longer be any degree of civil governance over ecclesiastical issues and he rewrote old rules to his advantage.

One of Laurentius's charges against Symmachus claimed that the latter had violated a senate resolution issued under Odoacer (who had become king of Italy in 476) by alienating ecclesial property, ${ }^{164}$ thereby committing sacrilege and forfeiting his episcopal position. In response, Symmachus summoned a synod to reject the resolution and to issue a new set rules against the alienation of ecclesial property in the form of a canon. The purposes of the canon were (1) to assert episcopal jurisdiction over ecclesiastical rule-making; (2) to subordinate civil law to canon in matters ecclesiastical; and (3), above all, to exonerate Symmachus from Laurentius's charge. The differences between the senate resolution of 483 and Symmachus's synodal canon of 501/2 show that Symmachus rewrote the rules so that his actions could not be considered sacrilegious.

In what follows, I first describe the charge in more detail. Then, I explain how Symmachus responded to it. Finally, I show that although Symmachus's stratagem of pushing civil authorities out of ecclesiastical matters worked in the short term, in the long term the century-long (or more) habit of negotiating ecclesiastical affairs among both civil and ecclesiastical authorities prevailed.

Symmachus's opponents leveled a complaint against him to King Theodoric in $501 / 2 .{ }^{165}$ One issue they raised concerned ecclesial property. According to the 
entry on Symmachus in the Laurentian Fragment, Symmachus "was accused by the whole Roman clergy of squandering the estates of the church (ecclesiastica dilapidasse praedia) contrary to the decree observed by his predecessors, and of thereby entangling himself in the bonds of an anathema." ${ }^{166}$ The Liber pontificalis suggests that the exconsuls Festus and Probinus drafted the charges. ${ }^{167}$ A council held in several sessions from sometime in August to October 23, 501/2 vindicated Symmachus. ${ }^{168}$ Laurentius held a synod to appeal the decision. Symmachus called a countersynod to that of Laurentius, and it is on this occasion that he specifically defended himself against the charge of maladministration of ecclesial property.

Symmachus presided over the counter-synod, which met on November 6, 501/2 at Saint Peter's Basilica. The synod undermined a longstanding procedure of operation in which bishops petitioned for civil laws to regulate ecclesiastical affairs. The synod addressed a senate resolution issued by the praetorian prefect Basilius in 483. The resolution, as cited in the synodal acts, says that it was issued in response to Bishop Simplicius of Rome's dying request regarding two issues: (1) that an election for his successor be not held without Basilius's consent; and (2) that ecclesial property be safeguarded from alienation both during the period of papal vacancy and under the tenure of all future popes. Simplicius, like many bishops before him, had sought civil enforcement of ecclesiastical regulations. Symmachus's synod, however, motioned to consider the edict void on the grounds that (1) it was written by a layperson, (2) that laypersons could not regulate the affairs of the church, and (3) that no pope or deputy metropolitan had signed it. To rephrase the council's words in terms of procedure, the council claimed that a canon ought to precede any law pertaining to ecclesiastical affairs. The synod replaced the resolution with a canon against the alienation of ecclesial property. As I will show, the canon permits more exceptions to the rule than the edict does, so as to exonerate Symmachus of sacrilege. ${ }^{169}$

Simplicius had given the praetorian prefect a mandate (mandatus) that the prefect, under penalty of oath ("by the adjuration of God" [sub dei obtestatione]) should ensure that no ecclesial property would be lost during the period of transition after Simplicius's death. ${ }^{170}$ The prefect carried out Simplicius's mandate by calling a meeting of the senate and issuing a senate resolution, a law. The law stated that no ecclesial property could be alienated. Exception was made only for things that could not be kept for a long time, such as fastenings on vestments made of precious stones, gold, or silver. These things could be sold at a fair price to pay the salary of a cleric. The law anathematized anyone who violated the rule.

There are two important differences between the senate resolution and Symmachus's canon. I will explain the first here, but I will postpone discussion of the second to the end of this case study. The first lies in the exception clause. Symmachus's canon allowed urban buildings for which the cost of maintenance exceeded the property value to be alienated. These are the sorts of properties that Symmachus probably alienated and was therefore charged with sacrilege by Laurentius 
and his supporters. Symmachus rewrote the rule so that his actions would not be illegal. ${ }^{171}$ Ennodius, Symmachus's apologist, does not deny the charge. ${ }^{172}$ Symmachus avoided the penalty of the edict by undermining its validity and instituting a canon of his own in its place.

The Council of Chalcedon about half a century earlier in 451 had decided that civil mandates which violated ecclesiastical canons would be considered void. Cecropius, the bishop of Sebastopolis, made the following motion and the synod and presiding civil authorities agreed:

So that your authority may not be saddled with receiving individual plaints, and so that we too should not be overburdened, we ask that the mandates procured by people in every province to the detriment of the canons should be incontrovertibly nullified, and that in all matters the canons should prevail—for in this way will both the faith be protected and each church have security-, and also that it should not be permitted to consecrate anyone contrary to the canons. ${ }^{173}$

The Council of Chalcedon effected a decision that would prevent conflict between canons and laws but that would continue to allow laws to enforce canons.

Symmachus's council went a step further from the decision of the Council of Chalcedon. Laws did not only have to be concordant with canons. Canons had to have temporal precedence over laws. In other words, laws should only reiterate what canons already state. Bishop Simplicius's testamentary mandate and the praetorian prefect's fulfillment of it violated the procedure on which Symmachus's council insisted: that ecclesiastical rules should be made in council and that civil laws should only reinforce them.

Symmachus did succeed in retaining his position as the bishop of Rome, despite Laurentius's charge, but the story does not end there. I propose reading a precept issued by King Theodoric five to seven years later as a direct response to the conflict between the senate resolution of 483 and the canon of 501/2. It is important to name at this point the second significant difference between the senate resolution and Symmachus's canon. Symmachus added a rule on usufruct: no usufruct could be granted to rural ecclesial property (only those clerics, captives, and pilgrims who were already usufructuaries prior to the synod could retain the usufruct). Around the time that the schism ended and Laurentius died, Theodoric wrote the following to the senate in 507/8. It directly addresses the same matter of usufruct: ${ }^{174}$

A suggestio has come to our [attention], father senators, concerning a benefit announced about the church, and an ordinatio of your sacred assembly strikes at the pleasing hearts of our clemency. Despite the fact that, after the venerable synod, your ordinatio alone should suffice for such a decree of judgment, yet in response to your petition we have granted a responsum with this imperial pronouncement (praesentibus oraculis): that it is not lawful for any overseer (antistiti) of the church anywhere to transfer property by means of alienation. They will bestow its usufruct 
on whomever they wish in fairness. The transfer of things ought to be of no effect even by the will of the pontiff alone or for the payment of clerics in any foreign place or by a statute of the church. A judgment is profane as long as it violates this part of the dispensation: while something belongs to the church and someone wishes to have it, persons claim for themselves as private a contract for the usufruct of a thing. Therefore, if someone takes forbidden things by impious attempts and wishes to take something beyond its usufruct with a bishop or cleric dispensing [it], the alienated thing in addition to its fruits are vindicated to the venerable praesul. ${ }^{175}$

If we understand ordinatio as a reference to the senate resolution of 483 , then Theodoric not only declares valid the document that Symmachus tried to undermine. Theodoric also lends his own imperial weight to the decision because he issued the responsum, which forbids the alienation of ecclesial property altogether and allows episcopal discretion in the usufruct of ecclesial property. Most importantly, Theodoric does not include the major exceptions that Symmachus and his council allowed. If we read the precept in the way that I have suggested, then Symmachus's efforts to change the nature of the relationship between church and state did not succeed.

In sum, Simplicius of Rome used his will for postmortem regulation of ecclesial property. His effort succeeded and resulted in a law. Two decades later, Symmachus used procedural grounds to question the law and the relationship of church and state, though his ulterior motive was to exonerate himself from a charge of sacrilege. Symmachus's attempt to use ecclesiastical court to overrule civil law met with a response from Theodoric himself, who reinforced civil law in no uncertain terms.

As we saw earlier, Cyril of Alexandria had also used his will as a means to control ecclesial property during a period of transition: from his death to the successor's accession. Like that of Simplicius a few decades later, the legality of Cyril's will was contested. Cyril of Alexandria urged his successor with oaths on the holy mysteries to refrain from taking legal action against Cyril's family. Cyril's attempt at postmortem regulation of ecclesial property failed because Dioscorus did not heed the wish. Cyril's nephew tried first in civil court and then in ecclesiastical court to force Dioscorus's compliance but failed both times. Most importantly, the ecclesiastical court-namely, the Council of Chalcedon-agreed with both Dioscorus's decision and that of the civil official who backed him. In general, the acts of the Council of Chalcedon show efforts to maintain cooperation between church and state.

In the fifth century, dying bishops tried to facilitate administrative transition by means of a legal document: the will. ${ }^{176}$ Such a strategy created a situation in which ecclesiastical and civil authorities faced each other's rules. Civil authorities cooperated with ecclesiastics to such an extent that new laws could not be written to overrule existing canons. But cooperation was a two-way street, so likewise new canons could not be used to overrule existing laws, despite Symmachus's assertions to the contrary. 
The application of Roman legal principles on res sacrae to Christian consecrated things turned churches and their associated properties into divinely protected places - that is, to places that were owned by no one. The extant evidence of laws and canons shows that bishops were already treating ecclesial property as inalienable before any laws explicitly endorsed the view that Christian holy places are divinely protected.

The divine protection of ecclesial properties meant that special privileges were accorded to them. It was the bishop's responsibility as chief administrator to honor those privileges or else face the charge of sacrilege. As the laws and canons discussed above demonstrate, the details of exemption clauses and the boundaries of episcopal discretion could change from decade to decade and vary from region to region. Details aside, jurists and bishops actively fashioned a concrete idea of "the sacred" and enforced regulations they created to propound and apply the idea. The cases of Ibas of Edessa and Dioscorus of Alexandria offer examples of how such regulations were enforced and new regulations were promulgated. The case of Symmachus of Rome brings to light examples of both cooperation and friction between the civil and ecclesiastical rule-making bodies over the administration of ecclesial property.

The first corollary to the legal-canonical definition of res sacrae was that such things were divinely protected. The next chapter turns to the construction of a second corollary: because such places were divinely protected, they might also serve as places of sanctuary-places where the needy could find and receive God's protection. Juristic pedagogy did not teach this second corollary, but bishops actively petitioned for legal recognition of churches as protecting spaces. 